\title{
OBITUARIES
}

Sir Eóward Bailey, M.C., F.R.S.

SIR EDwaRd BAILEY, a former director of the Geological Survey of Great Britain and the Museum of Practical Geology, also for seven years previously professor of geology in the University of Glasgow, died in London on March 19, at the age of eighty-three.

The range of his international reputation may be gauged from his election to foreign membership of the national scientific academies of Belgium, Norway, Switzerland and the United States. This reputation mainly stemmed from his investigations over a long period in the south-western Grampians and Inner Hebrides, where he played a prominent part not only in explaining the complicated sequences and the repetition of rock types in schists, but also in unravelling the succession of events in ancient volcanic episodes. Much of his work in other fields, though less well known, proved equally stimulating. His strongly developed sense of the heroic, however, brought praise from some but impassioned criticism from others.

Edward Battersby Bailey was born at Marden in Kent, where his father was a medical practitioner. When the family moved to Kendal, Bailey attended Kendal Grammar School, whence, in 1899, he won an open scholarship to Clare College, Cambridge. There he showed outstanding ability by achieving first-class honours in both geology and physics in Part II of the Natural Sciences Tripos in one year (1902); also in that year he joined the Scottish branch of the Geological Survey of Great Britain. This service with the Geological Survey had two interruptions: the first between 1915 and 1919, when Bailey served with the Royal Garrison Artillery and was severely wounded on the Somme in 1916, and again near Ypres in 1918; he was awarded the Military Cross and the French Croix de Guerre with palms, and he was made a Chevalier of the Legion of Honour. At the close of 1929 he left the Geological Survey for the geology chair at Glasgow, which he relinquished in March 1937 to return to the Geological Survey as its director, an appointment which he held for eight years, culminating in his knighthood.

In his book The Geological Survey of Great Britain (1952) Bailey recorded his enjoyment on joining the Geological Survey at such an invigorating centre as Edinburgh, for he realized that he was to research "among a jostling crowd of problems awaiting solution". Having acquired at school and at his university extraordinary physical strength and mental courage, he became dedicated to geological problems and his alert mind brought insight to them. His flair for original thought was aided by a skill in reassessing and building on the observations made by others. He soon succeeded in clarifying the Carboniferous volcanic history of the Campsie Fells in Stirling. shire. In Argyllshire, with C. T. Clough and H. B. Maufe, he demonstrated in 1909 that Devonian lavas and tuffs flanking Glen $\mathrm{CO}-$-which occupied an elliptical aroa bounded by a curved fault and measuring nearly 30 square miles-had been let down more than a thousand feet into the midst of Highland schists. This 'cauldron subsidence' was inferred to be sub-aerial and to have beon formed, in part at least, at the time of the volcanic activity; it was proved to be partly contemporaneous with the broken ring of intrusive igneous rocks associated with the curved fault. Shortly after the announcement of this discovery came that of Bailey's interpretation of the Highland schists in the neighbourhood of Fort William and Ballachulish. He claimed them to have been folded in a recumbent manner and accompanied by fold faults or slides which in places had cut out great thicknesses of rock. But R. G. Carruthers (who died on the day of
Bailey's cremation) in 1913 disputed the correlation made by Bailey of some of the units in the succession. Bailey was unconvineed of his errors until 1930 when others had pointed out that current bedding provided incontrovertible evidence of the original order of stratal deposition; he then corrected various details in his interpretation of the tectonic pattern, but the concept of recumbent folding has survived. Bailey's final reassessment of this work appeared in his second edition of the Geology of Ben Nevis and Glen Coe (1960).

Further distinguished work was undertaken by Bailey and his colleagues in the Inner Hebrides, where they elucidated the complicated history of the Tertiary volcanic centre in Mull and the various stages of the igneous activity there. Sir John Flett in 1937 stated this to be one of the most wonderful chapters of the Geology of Britain. Here in Mull, Bailey described gravitational differentiation, ring bosses, pillow lavas, crater lakes and ring dykes. The last name took its currency from Bailey's first usage in 1915. After his return from the First World War in 1919, Bailey was placed in charge of the Survey's West Highland field unit. $\mathrm{He}$ took over supervision of the team-work in other parts of Mull, Ardnamurchan and Coll, and he brought to publication the one-inch geological map of Mull and the two classical memoirs thereon (1924, 1925). During this period he re-examined the Cretaceous sands on the west side of Loch Aline and from their very high silica content he deduced them to be the desert shore sands of the Chalk sea. The $\mathrm{F}_{\theta_{2}} \mathrm{O}_{3}$ impurity being only 0.02 per cent, the deposit was later developed as a source of optical glass sand, and between 1940 and the autumn of 1948 a quarter of a million tons were shipped from a mine excavated in it.

While at Glasgow, Bailey continued his investigation of the manifestations of Earth movement and, inspired by his studies with R. M. Field and L. W. Collet on the effects of Palaøozoic submarine landslipping near Quebec, he wrote with Dr. John Weir on faulting in Kimmeridge times which had produced spectacular effects off the coast of East Sutherland. $\mathrm{He}$ also wrote his book, Tectonic Essays: mainly Alpine (1937).

His plans for directing the Geological Survey were thwarted by the needs of the War years. The activities of the staff were then diverted to appraising, for concentrated utilization in the War effort, the country's natural mineral resources. Theso included coal, iron-ore, barytes, fluorspar, tungsten-ore, potash-feldspar, water and oil. The Survey's headquarters were partly occupied by another Government department, and as a spare-time activity Bailey was appointed in 1940 lieutenant commanding the Geological Survey and London Civil Defence Region section of the Home Guard, which duties he undertook with enthusiasm until 1942. In 1943 he had a short spell in Malta to advise on water resources there. $\mathrm{He}$ retired in 1945. He continued geological work after retirement, a.t first in Iran, and then in Turkey, the latter with Prof. W. J. McCallien. In recent years with the last-named he studied a problem in Apennine tectonic geology.

His keen walking and mountaineering activities led him to support the Scottish Youth Hostels' Association, of which he was successively Glasgow District chairman, vice-president and honorary president. He much enjoyed writing biographies of geologists. His book on Charles Lyell was published in 1962, and before he died he had prepared a study on James Hutton.

Bailey was elected to the fellowship of the Royal Society in 1930 and he received a Royal Medal in 1943. From the Geological Society of London he received the Bigsby, Murchison and Wollaston Medals. Honorary 
doctorates were awarded to him by the Universities of Belfast, Birmingham, Cambridge, Edinburgh, Glasgow and Harvard.

His married life with Alice Meason started in 1914 and was ended by her death in 1956; they were devoted to each other and had a son and a daughter. In December 1962 he married Miss Mary Young, who survives him.

C. J. STUBBLEFIELD

\section{Dr. C. M. Merrihue}

Dr. Cratg M. Merrihue, physicist of the Smithsonian Astrophysical Observatory and associate of Harvard University, Cambridge, Massachusetts, died in a mountainclimbing accident on March 14, 1965.

Born in Schenectady, New York, on July 8, 1933, he was awarded the B.A. degree from Harvard University in 1956, and the Ph.D. from the University of California at Berkeley in 1964. He lived in Cambridge, Massachusetts, with his wife Sandra and their son Joffrey.

Dr. Merrihue's professional accomplishments were, of course, mainly ahoad of him. However, in his short career he demonstrated an unusual combination of theoretical skills and experimental aptitude, and made important contributions to science. His first published work placed upper limits on a $\beta$ - branch in ${ }^{124} \mathbf{I}$ by examining with a mass spectrometer the xenon with deuteron-irradiated tellurium. Other investigations helped determine the isotopic composition of the rare gases in several meteorites, with particular emphasis on xenon anomalies, which were being intensively studied in the laboratory of Prof. J. H. Reynolds at Berkeley, California.

One of Dr. Merrihue's most important discoveries was the finding of unusually large anomalies in xenon isotope composition in chondrules of the Bruderheim meteorite. These chondrules displayed the highest ${ }^{129} \mathrm{Xe} /{ }^{132} \mathrm{X}_{\theta}$ of any meteoritic material yet examined, and supported the suggestion of a very primitive origin for chondrules. For this work he received the first Nininger Meteorite Award.

His analysis showed large differences in the amounts of both anomalous ${ }^{129} \mathrm{X} \Theta$ and total xenon in different minorals of the matrix. These matrix xenon variations wore non- linearly correlated, and distinctly different from the xenon observed in all other chondrules investigated. He used these observations as further evidence for the in situ origin of excess ${ }^{129} \mathrm{Xe}$. As a result of these investigations, Bruderheim is at present the only meteorite for which we have such complete xenon and krypton data on separated. minerals.

In conjunction with the Bruderheim measurements, Merrihue embarked on a series of computer calculations. These included. Monte Carlo calculations of the production of xenon isotopes by possible early solar-system irradiations of meteoritic target elements, and investigations of rare-gas diffusion. He also noted the great power of combining neutron activation of meteorites with mass spectrometry of the rare gases as a tool for determining the chemical abundance, and in favourable cases the isotopic abundance, of a list of elements. This technique also provides an elegant method of potassium-argon dating of small samples. He also made rare-gas measurements of a magnetic separate from a Pacific red-clay deep-sea sediment, and found isotopic anomalies suggesting the possible presence of extraterrestrial dust in this material. These applications of mass spectrometry to problems of meteorites and cosmic dust and of the history of the solar system were imaginative and fruitful and provided many important new data.

Merrihue was a quiet, modest, unassuming man with intense enthusiasm for life. He was deeply involved in the public problems of his time, taking an active interest in conservation, civil liberties, and political issues. $\mathrm{He}$ was concerned alike for the individual and for society.

A skilful mountain climber, he had led an expedition to the Andes, had climbed in British Columbia and in the Karakorams in Pakistan, and was planning an expedition to the Hindu Kush in Afghanistan. While he and Daniel Doody, a member of the American Everest Expedition, were climbing on the side of Mt. Washington, they both fell and were killed.

Because of his theoretical interests and practical skills as a scientist, and because of his experience as a mountain climber, Dr. Merrihue was a conspicuous candidate for the position of scientist on America's first manned expedition to the Moon.

\section{NEWS and VIEWS}

\section{Chief of the C.S.I.R.O. Division of Biochemistry and General Nutrition: Dr. H. R. Marston, F.R.S.}

IN August 1965, Dr. Hedley R. Marston relinquishes the position of chief of the C.S.I.R.O. Division of Biochemistry and General Nutrition, Adelaide, having reached the age of retirement. When the Division was establishcd in 1944 he was appointed as its first chief. He had been associated with the division of animal nutrition since its formation in 1927 . It has always been Marston's firmly expressed belief that the only safe road to practical advance in applied science is through the understanding of the underlying natural phenomena, and his own research fully confirms this. His earlier work included investigations of the thermo-dynamics of ruminant nutrition, and fundamental studies of the protein requirements for wool production. His name, however, is most widely known for his work on the nutritional importance of trace elements, in particular of cobalt, copper and zinc. He and his colleagues were responsible not only for showing that soil deficioncies of copper and zinc prevented the growth of many food crops and that deficiencies of either cobalt or copper may prove fatal to sheep, but also for tracing an ultimate role of cobalt to its incorporation, after conversion to vitamin $\mathrm{B}_{12}$ by micro-organisms of the rumen, into methyl- malonyl co-isomerase. It must be a lasting satisfaction to him that his work has brought prosperity to many parts of the world, and not least to the region in which he was born and lived, for his birth-place was Bordertown, on the edge of what was then known as the "ninety mile desert'. Marston, like other men of high mental stature, is never slow to acknowledge his debt to others. In conversation, he mentions many names with affection, perhaps most frequently those of C. J. Martin, his former chief, Sir David Rivett, who was the architect of the Australian C.S.I.R., and Sir Frederick Gowland Hopkins, in whose laboratory he worked in 1936-37.

\section{Zoology at the University of Cambridge:}

Prof. T. Weis-Fogh

Dr. Torkel WeIs-Fogh, who has been elected to succeod Prof. C. F. A. Pantin (Nature, 183, 506; 1959) as professor of zoology in the University of Cambridge from October 1966, was born in Aarhus, Denmark, on March 25, 1922. He studied zoology in the University of Copenhagen and already as a student of twenty-two he showed his extraordinary scientific talent by winning a gold medal for a zoological prize essay on soil ecology. In 1947 he took his degree as Magister scientiarum in zoology and became assistant in research to the retired Prof. August 